\title{
Concealed Environmental Threat in the Coastal Region Requires Persistent Attention: The Panglao Island, Philippines Example
}

\author{
Daniel Edison Husana ${ }^{1,2^{*}}$, Tomohiko Kikuchi ${ }^{2}$ \\ ${ }^{1}$ Environmental Biology Division, Institute of Biological Sciences, College of Arts and Sciences, University of the Philippines Los \\ Baños, College, Laguna, Philippines; ${ }^{2}$ Global Center of Excellence for Environmental Studies, Graduate School of Environment and \\ Information Sciences, Yokohama National University, Yokohama, Japan. \\ Email: *dehusana@gmail.com
}

Received June $25^{\text {th }}, 2013$; revised July $26^{\text {th }}, 2013$; accepted September $1^{\text {st }}, 2013$

Copyright (C) 2013 Daniel Edison Husana, Tomohiko Kikuchi. This is an open access article distributed under the Creative Commons Attribution License, which permits unrestricted use, distribution, and reproduction in any medium, provided the original work is properly cited.

\begin{abstract}
Panglao is a small island in the central part of the Philippines and well-known for its world-class beaches and coral reefs. These attract millions of tourists each year thus providing business opportunities and employment, a significant source of revenue for the local economy. Moreover, this island lies in a region with high biodiversity. However, the escalating activity is so alarming that the negative effect to the local environment is very much prevalent but not easily perceivable. Analysis and measurement of physico-chemical parameters of the groundwater revealed high levels of human-induced contaminants. This subterranean pollution was attributable to the leakage of septic tanks, artificial application of disinfectants as well as infiltration of saltwater from the ocean due to over-extraction of groundwater in order to meet the increasing demand for water. The community within the area was oblivious because human impacts to the environment appear to be virtually absent. These findings clearly suggest the concealed vulnerability of the groundwater resources from human activities. Higher standard for the coastal development plan, strong implementation of environmental policy and immediate government action is deemed necessary.
\end{abstract}

Keywords: Hidden Environmental Threat; Groundwater; Coastal Region; Panglao Island; Philippines

\section{Introduction}

The coastal areas are known to be one of the world's fastest growing areas for development ever since the ancient times. However, development is usually accompanied by environmental threats if not properly managed and, more often than not, people and authorities react when the problem is already apparent (or the surrounding community is already affected). The case of the underground system that is not readily visible is oftentimes out of people's concern making it the least priority. Humans do not care much about their activities on the surface environment that may impact the hidden subsurface environment. Over extraction of groundwater, for example, could result to the decline of the water table that causes loss of buoyant support to the overlying rocks, which will eventually lead to catastrophic land subsidence [1].

"Corresponding author.
Overexploitation and mismanagement of groundwater resource could lead to the depletion and degradation of water quality [2] as well as saltwater intrusion. Moreover, changes in the physicochemical properties of groundwater are known to affect the physiological development of aquatic biota (e.g. [3-6]). The overall effect will eventually affect the well-being of the human population who are at the losing end. People should therefore be aware of such concealed environmental threats before it becomes too late.

Panglao is a small island located in the central part of the Philippines (Figure 1). It is divided into two municipalities, Dauis on the east and Panglao on the west, with a total land area of $95.07 \mathrm{~km}^{2}$ and bounded by 49.17 kilometers of coastline. The island's population in 2007 is 62,083 with an average growth rate of $1.5 \%$ according to the record of the National Statistics Office (NSO) of Dauis and Panglao municipalities. Panglao Island is economically important for the province of Bohol because of 


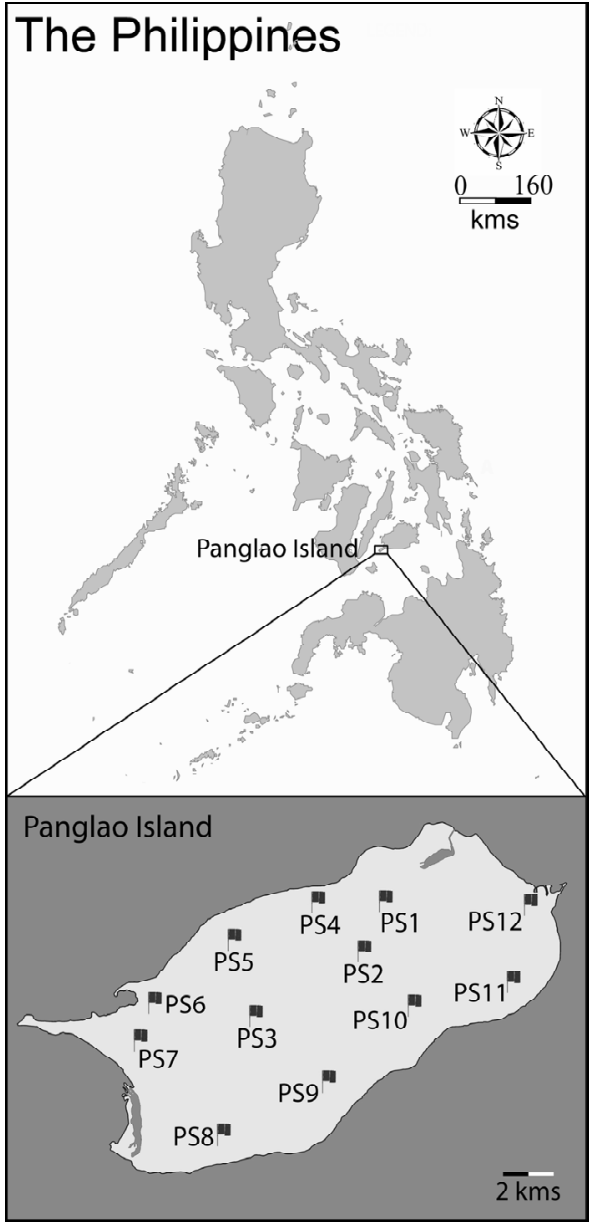

Figure 1. Map of the Philippines showing the sampling sites in Panglao Island.

its tourism industry. This island is known globally for its world-class beach resorts making it frequented by many local and foreign tourists. Bohol provincial tourism office recorded an escalating number of visitors from 128,899 in 2003 to 282,498 in 2008 and was projected by the Bohol Provincial Planning and Development Office (PPDO) to be four times higher in the next ten years and that is on top of its local population that is also increasing every year. Incidentally, [7] detected high concentrations of $\mathrm{NO}_{2}^{-}, \mathrm{NO}_{3}^{-}$and $\mathrm{Cl}^{-}$in the groundwater of Panglao Island and suggested to have further investigations on what could be the possible cause/s or source/s of the contamination.

On the other hand, Panglao Island is rich in biodiversity. Reference [8] reported that initial estimates of more than 7000 species were sampled during the 2004 marine expedition in the surrounding sea. This does not include the terrestrial species and those species inhabiting the groundwater of this small island (e.g. [9-12]). While unique cave (groundwater) species have been discovered and described in various parts of the Philippines in recent years (e.g. [13-15]), some of which belong to a higher taxa like new genus [16]) or even a new family [17], it's also possible that there are more undescribed species inhabiting the groundwater of Panglao Island.

This study aimed to assess and identify the problems that exist in a "healthy-looking" coastal area. We intend to provide examples of environmental issues that are frequently overlooked and ignored but could be a serious threat if not properly checked.

\section{Materials and Methods}

Water samples were collected from 12 sampling points (indicated PS1 to PS12) from deep wells and caves in the island of Panglao, Bohol, Philippines (Figure 1) in May 2011. They were analyzed at the University of the Philippines-Natural Sciences Research Institute (UP-NSRI) for microbial content and chemical contaminants.

\subsection{Microbial Analyses}

Separate analyses were conducted for environmental samples (water samples not ideal for drinking) and those water that is used for drinking.

\section{1) Environmental Water Samples}

The samples were serially diluted up to $10^{-2}$ analyzed by multiple tube fermentation technique (MTFT) using 5 of $1-\mathrm{ml}$ portions of the undiluted sample $\left(10^{0}\right)$ and the $10^{-1}$ and $10^{-2}$ dilutions. The presumptive test for coliform bacteria was done on single strength lauryl sulfate tryptose broth (LST). The LST tubes were incubated at $37^{\circ} \mathrm{C}$ and observed for gas production within 24 - 48 hours. To confirm the presence of coliform bacteria, gassing LST tubes were sub-cultured into brilliant green lactose bile broth (BGLB). BGLB tubes were incubated at $37^{\circ} \mathrm{C}$ and observed for gas formation within 24 - 48 hours. Gassing LST tubes were likewise sub-cultured into EC broth to confirm the presence of fecal coliforms. EC tubes were incubated at $44^{\circ} \mathrm{C}$ and observed for gas formation within 24 hours.

The most probable number (MPN) of coliform bacteria per $100 \mathrm{~mL}$ sample were determined from the MPN table for $10^{0}, 10^{-1}$ and $10^{-2}$ dilutions.

\section{2) Drinking Water Samples}

The samples were analyzed by MTFT using 5 of 20$\mathrm{mL}$ volumes of the sample on triple strength LST, 5 of $10-\mathrm{ml}$ volumes in double strength LST and $5 \mathrm{of} 1-\mathrm{ml}$ and $0.1-\mathrm{ml}$ volumes on single strength LST. Procedures to determine presumptive and confirmed fecal coliform levels, as in the environmental water samples, were followed.

The water samples contained high levels of coliform bacteria for drinking water, hence, values obtained using $20-\mathrm{ml}$ volumes were not considered. The MPN levels of coliform bacteria were based on 10-, 1- and $0.1-\mathrm{ml}$ vol- 
umes of the sample.

\subsection{Water Physico-Chemical Analyses}

Dissolved oxygen, conductivity, salinity and temperature were measured using YSI 85 while $\mathrm{pH}$ was measured using Custom Waterproof $\mathrm{pH}$ meter. These parameters were measured in situ during water sampling.

Chloride and nitrate were analyzed using ion chromatography, nitrite using colorimetric N-(1-naphthyl) ethylene diamine dihydrochloride reagent method while Atomic Absorption Spectrophotometry (AAS) Flame method was used to analyze sodium following the standard methods for the examination of water and wastewater [18].

\subsection{Survey and Interview}

People aged 14 to 84 years old, $90 \%$ of them have resided in Panglao Island for 10 years or more, were interviewed during our survey in 2011. One hundred fifty (150) respondents were selected randomly from different areas of the island of which 11 were discarded due to questionable response leaving a total of 139 valid respondents. Questions regarding family background, their environmental and economic points of view on Panglao Island were asked and scored in a sheet.

\section{Results and Discussion}

\subsection{Microbial}

The results show high levels of coliform bacteria in all the groundwater sampling sites in Panglao Island (Figure 2). It ranged from 2 to $16,000 \mathrm{MPN} / 100 \mathrm{~mL}$. All the sites that were sampled for environmental water quality test were all contaminated with fecal coliform bacteria with the highest concentration in site PS4 (16,000 MPN/ $100 \mathrm{~mL})$ and with the least concentration in site PS1 (20 MPN/100mL). All the wells that are currently being used for drinking water (PS2, PS3, PS5, PS9, PS10 and PS11) are contaminated with fecal coliform bacteria. The highest concentration was detected in site PS2 (1600 MPN/ $100 \mathrm{~mL}$ ) and least in PS10 (2 MPN/100mL).

None of the sites passed the standard for drinking water or for recreation use. This is a clear indication that even though there is no apparent sign of human disturbance, deterioration of groundwater system is very evident.

\subsection{Physico-Chemical}

Table 1 summarizes the environmental parameters of groundwater obtained from Panglao Island. The $\mathrm{pH}$ was all within the normal range from 6.89 to 7.93 . Dissolved oxygen (DO) ranged from 2.40 to $6.34 \mathrm{mg} \cdot \mathrm{L}^{-1}$, PS3 having the highest concentration and PS6 the lowest. Temperature ranges from $27.7^{\circ} \mathrm{C}$ to $31.6^{\circ} \mathrm{C}$. Water conductivity ranged from 0.002 to $57.4 \mathrm{mS}$ and salinity from $0.1 \%$ to $6.7 \%$, PS6 has the highest concentration of both parameters while PS5 has the lowest. Low DO concentration in site PS6 is quite noticeable as well as high EC and salinity.

Sodium ion concentrations (Figure 3) ranged from 53.4 to $2120 \mathrm{mg} \cdot \mathrm{L}^{-1}$. Site PS6 has the highest concentration while PS12 has the lowest. Chloride ion concentrations (Figure 3) ranged from 33.8 to $3430 \mathrm{mg} \cdot \mathrm{L}^{-1}$ with the highest concentration in PS6 and lowest in PS12. Note that PS12 has higher concentration of sodium than chloride unlike the other sites in which chloride ions are almost twice the sodium ions concentrations.

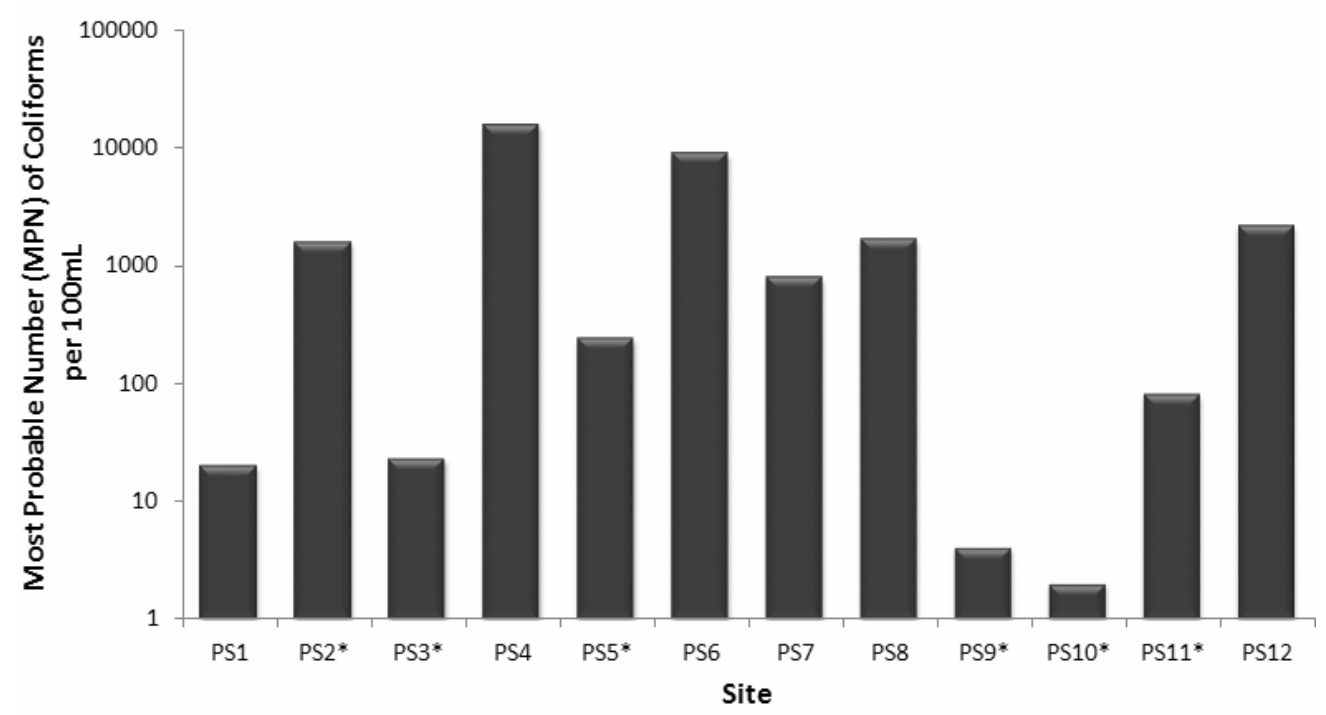

Figure 2. Coliform counts of Panglao Island groundwater samples. Sites with asterisk (*) indicate drinking water samples. 
Table 1. Aquatic environmental parameters of groundwater in Panglao Island.

\begin{tabular}{|c|c|c|c|c|c|c|}
\hline Sampling site & Coordinates & DO $\left(\mathbf{m g} \cdot \mathbf{L}^{-1}\right)$ & Conductivity (mS) & Salinity & Temp $\left({ }^{\circ} \mathrm{C}\right)$ & pH \\
\hline PS1 & $\mathrm{N} 9^{\circ} 37.300 ; \mathrm{E} 123^{\circ} 49.078$ & 3.20 & 2.098 & 1.0 & 29.2 & 7.02 \\
\hline $\mathrm{PS}^{*}$ & $\mathrm{~N} 9^{\circ} 36.420 ; \mathrm{E} 123^{\circ} 48.976$ & 5.12 & 0.754 & 0.3 & 28.7 & 6.89 \\
\hline $\mathrm{PS}^{*}$ & $\mathrm{~N} 9^{\circ} 35.623 ; \mathrm{E} 123^{\circ} 47.088$ & 6.34 & 1.723 & 0.8 & 28.5 & 7.31 \\
\hline PS4 & $\mathrm{N} 9^{\circ} 37.523 ; \mathrm{E} 123^{\circ} 48.059$ & 5.75 & 11.340 & 6.1 & 27.8 & 7.25 \\
\hline $\mathrm{PS}^{*}$ & $\mathrm{~N} 9^{\circ} 36.703 ; \mathrm{E} 123^{\circ} 46.750$ & 5.66 & 0.002 & 0.1 & 28.1 & 6.97 \\
\hline PS6 & $\mathrm{N} 9^{\circ} 35.521 ; \mathrm{E} 123^{\circ} 45.034$ & 2.40 & 12.540 & 6.7 & 28.0 & 7.13 \\
\hline PS7 & $\mathrm{N} 9^{\circ} 34.899 ; \mathrm{E} 123^{\circ} 44.771$ & 4.38 & 2.359 & 1.1 & 27.8 & 7.20 \\
\hline PS8 & $\mathrm{N} 9^{\circ} 33.316 ; \mathrm{E} 123^{\circ} 46.486$ & 4.30 & 7.540 & 3.7 & 28.6 & 7.19 \\
\hline $\mathrm{PS}^{*}$ & $\mathrm{~N} 9^{\circ} 34.207 ; \mathrm{E} 123^{\circ} 48.378$ & 5.68 & 2.517 & 1.2 & 27.7 & 6.93 \\
\hline $\mathrm{PS} 10^{*}$ & $\mathrm{~N} 9^{\circ} 35.442 ; \mathrm{E} 123^{\circ} 49.677$ & 5.17 & 1.608 & 0.8 & 28.4 & 6.90 \\
\hline PS1 $11^{*}$ & $\mathrm{~N} 9^{\circ} 35.855 ; \mathrm{E} 123^{\circ} 51.445$ & 5.22 & 1.133 & 0.5 & 28.1 & 7.00 \\
\hline PS12 & $\mathrm{N} 9^{\circ} 37.466 ; \mathrm{E} 123^{\circ} 51.928$ & 3.73 & 0.839 & 0.4 & 27.9 & 7.45 \\
\hline
\end{tabular}

*Drinking water samples.

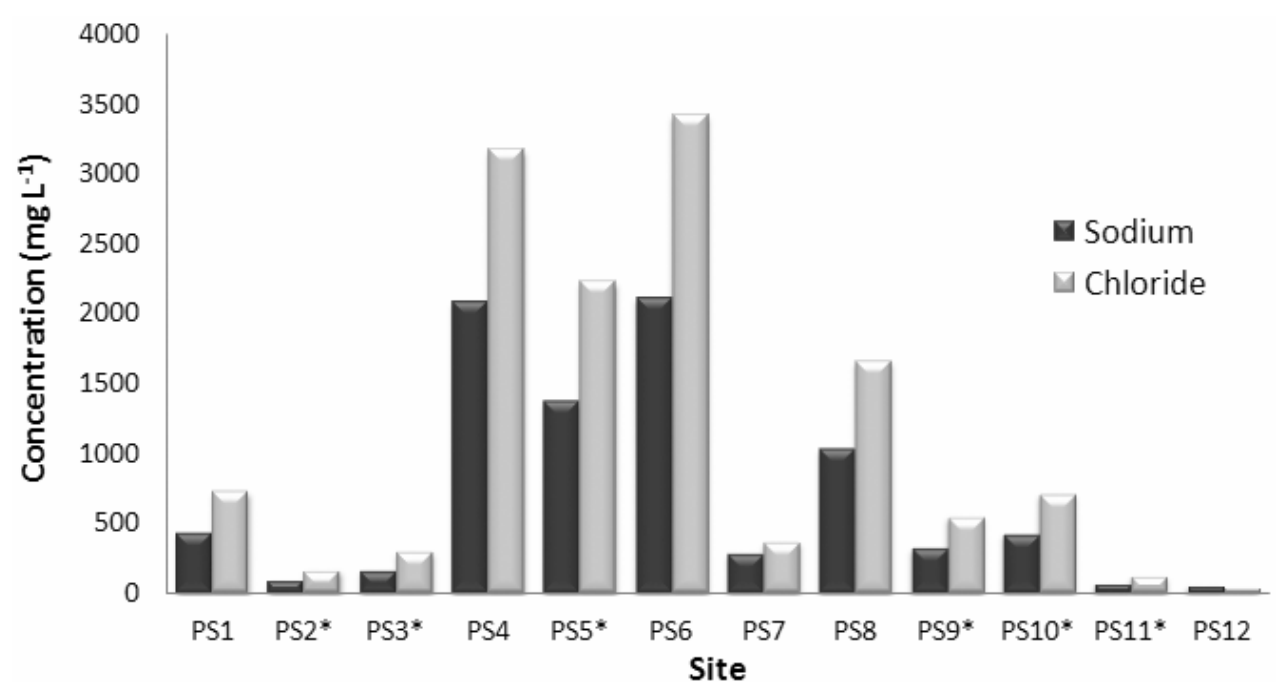

Figure 3. Concentrations of sodium and chloride ions in various parts of Panglao Island. Sites with asterisk (*) indicate drinking water samples.

Nitrate concentrations (Figure 4) ranged from 7.2 to $61.9 \mathrm{mg} \cdot \mathrm{L}^{-1}$ with the highest concentration in PS12 and lowest in PS3. PS1 and PS12 sites both have above maximum contaminant level (MCL) for $\mathrm{NO}_{3}-\mathrm{N}(11.59$ and $14.07 \mathrm{mg} \cdot \mathrm{L}^{-1}$ respectively). Nitrite concentrations on the other hand ranged from less than maximum detection limit (MDL) up to $0.025 \mathrm{mg} \cdot \mathrm{L}^{-1}$ (data not shown). This high concentration of nitrate in drinking water poses a serious threat to human health especially to babies. Nitratenitrogen concentration as low as 10 to $20 \mathrm{mg} \cdot \mathrm{L}^{-1}$ is known to cause illnesses and even deaths among infants under six months of age.

\subsection{Local People's Perspective}

Our random interviews with the local people gave some insights on the situation in Panglao Island as well as some perspective of the residents. Highest number of the respondents use municipal water supply $(38.7 \%)$ which is a centralized deep well in the island followed by those using purified (33.8\%). About fifteen percent (14.9\%) utilizes water from their private deep well for their daily consumption while the rest are using bottled water $(9.3 \%)$ and other sources not mentioned (3.3\%).

Twenty-seven percent $(27 \%)$ of the respondents noticed changes in the quality of water during their entire life in the island in terms of taste and color while $73 \%$ said there's no change, however, some of them commented that the water from the deep well tastes a little brackish.

In terms of the possible sources of pollution in Panglao the respondents admitted that the local people are the main source of pollution $(53.7 \%$ ) while the rest are coming from local industry $(19.9 \%)$, natural cause $(15.4 \%)$, tourism $(9.6 \%)$ and agriculture (1.5\%). In this respect, 


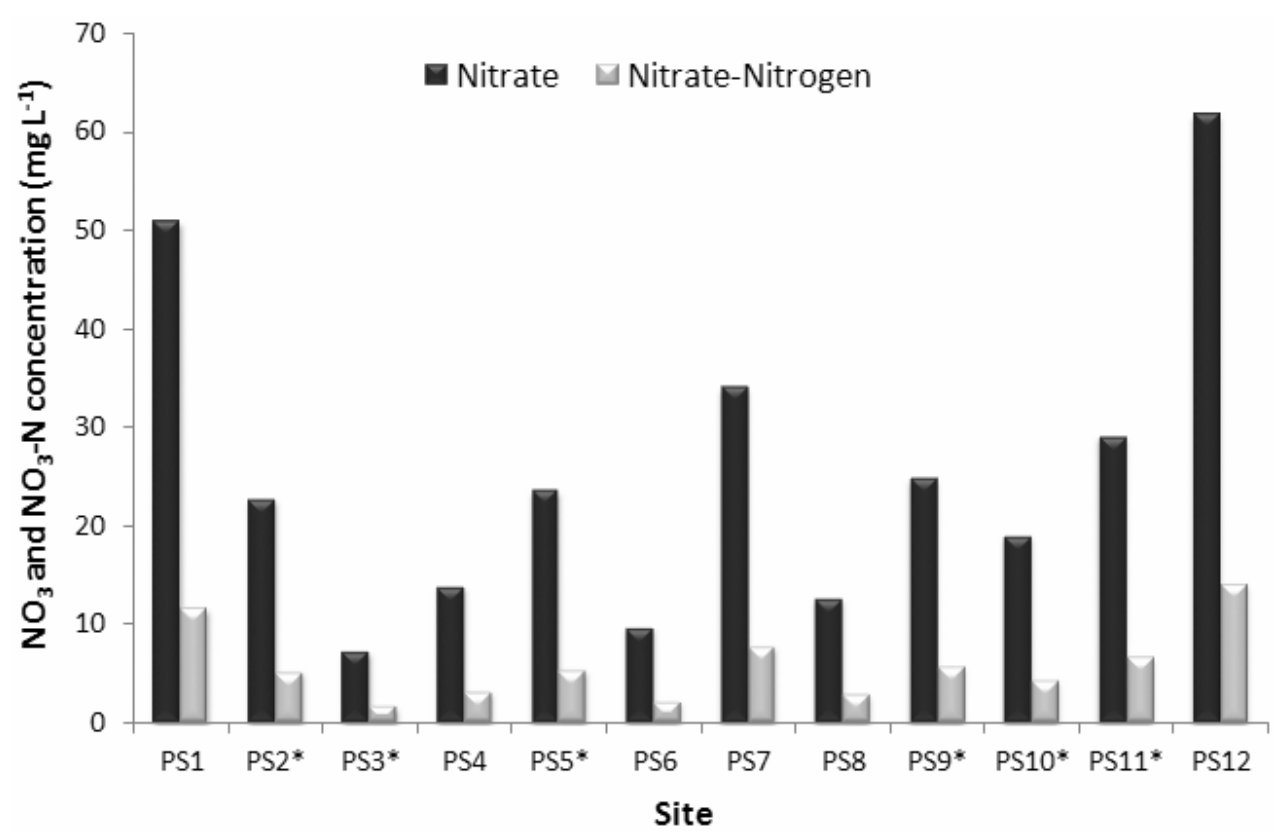

Figure 4. Nitrate and nitrate-nitrogen concentrations of groundwater in Panglao Island. Sites with asterisk (*) indicate drinking water samples.

most people believe that beaches $(51 \%)$ are the most threatened natural resource in Panglao Island as a result of island development. The other half believed that mangroves $(15 \%)$, groundwater $(13.6 \%)$ and caves $(12.9 \%)$ are also threatened while the smallest percentage of the respondents $(6.8 \%)$ is not aware of the threat. If pollution will not be controlled, $49 \%$ said that beaches would be the most affected followed by groundwater (21\%), mangroves $(10.2 \%)$ and caves $(9.5 \%)$. While $8 \%$ are not aware, $1.5 \%$ said that there is no threat at all.

Majority of the respondents $(46.6 \%)$ believed that tourism is the major source of local employment while $19 \%$ said it is the major driver for the development of Panglao Island. Others said that tourism causes the increase in population (17.2\%) and pollution (13.2\%) while $4 \%$ said it causes environmental destruction.

Most of the respondents (46.6\%) claimed that Panglao Island in general is a good place for business and employment opportunities. Others know that this island has high biodiversity (19\%), overcrowded and polluted (17\%), a paradise and tourist destination (13.2\%) and 4\% said it's a sanctuary for plants and animals.

\subsection{Potential Impacts to the Environment}

Tourism attracts migration, temporarily and permanently, because of the aesthetic value of the place as well as the employment and business opportunities. These can result to the increase in local population, which if not checked and regulated will skyrocket beyond the local environment's carrying capacity and the ecosystem's resilience to stressors. This chain reaction could lead to ecological disaster and collapse. The high concentration of nitrate, the presence of coliform bacteria and the increasing groundwater salinity is quite alarming. The presence of these pollutants in coastal groundwater is a clear indication of ignorance and invisible but potentially devastating impacts of human activities to the environment. Local population of the island relies on groundwater (municipal water supply) and the changes in its quality have made the people without a choice but to use purified or filtered water. This issue will become a bigger problem in the long run if the local residents could not afford the (more expensive) potable water for their basic needs.

Contamination of Panglao Island's groundwater with coliform bacteria could primarily be due to the current design of septic tanks as observed personally by the first author (see illustration in Figure 5). The lack of waterproof flooring allows the infiltration of waste from the septic tank through the porous limestone base. This contaminated water could easily disperse to the groundwater of the entire island as noticed with the water quality analyses. High chlorine concentration on the other hand could be attributable to the combination of seawater intrusion and application of free chlorine directly to the open wells to disinfect the water for drinking. Sanitation techniques however seem to be ineffective because coliform bacteria in the groundwater were detected.

The groundwater serves as corridor for migrating animals in areas where surface water such as rivers are not present $[19,20]$. It is also a refuge and breeding ground for some aquatic animals (unpublished report). In this 


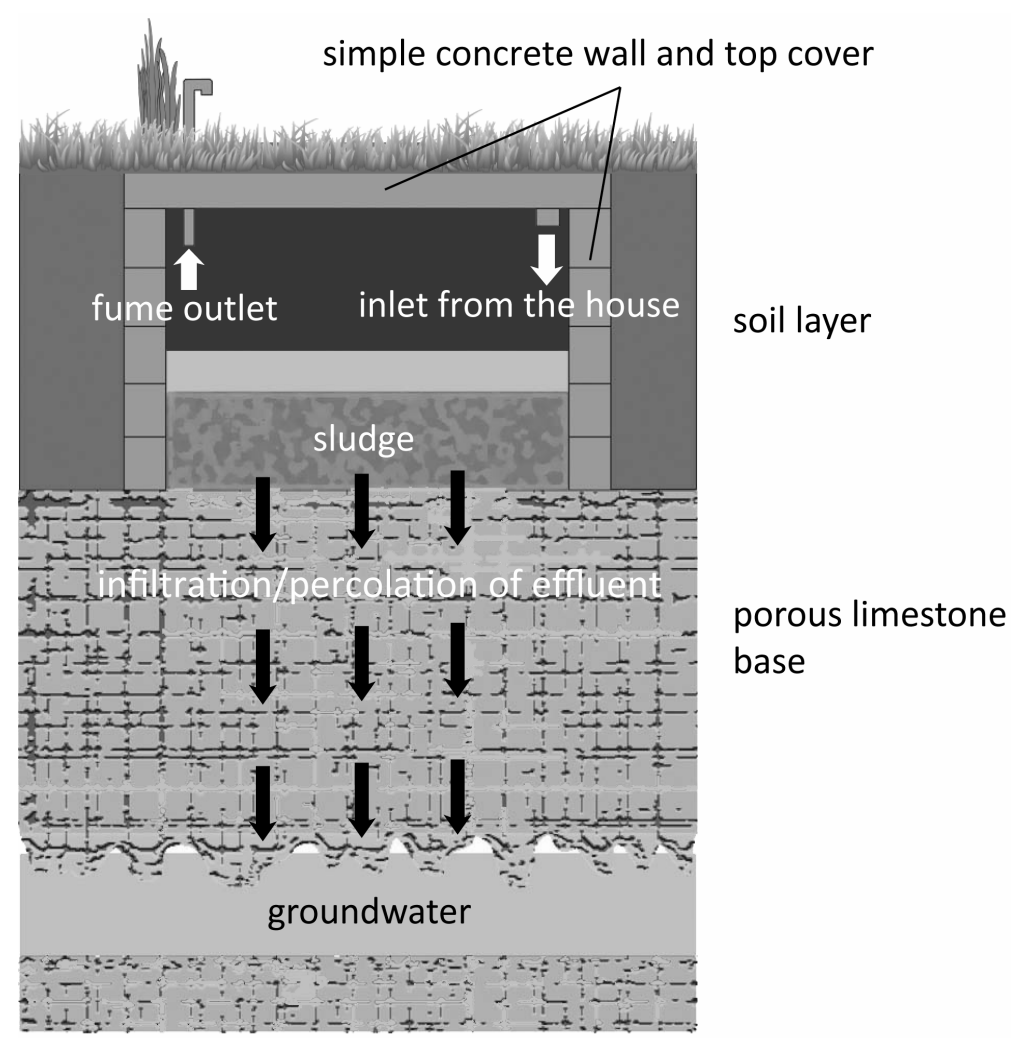

Figure 5. Conceptual model of the common design of septic tanks in Panglao Island illustrating the infiltration of effluent/ polluted water through the porous limestone base that causes contamination of the groundwater.

regard, the quality of groundwater will play a vital role in the survival of organisms that depend on it. Aquatic nutrients are important but their excess amounts could be detrimental to the health of the groundwater organisms.

\subsection{The Need for a Strategic Management Plan}

Panglao Island, though small, is rich in natural resources but these will vanish if not properly managed and taken cared of. Without strong consideration to the biodiversity and natural environment, the island's natural aesthetic quality will collapse in due time. Marine and coastal regions are known to be experiencing the fastest tourism growth among other areas in the world [21] and yet most people are still unaware of its negative impact on the fragile coastal ecosystems. Development of resorts along the coast is economically valuable but ecological consideration and proper management should be implemented in strictest sense. They should not threaten the biodiversity and selfishly exploit the natural resources for the benefit of the few; hence strong political support for sustainable development is deemed essential.

It is important to note that protecting the underground environment does not rely solely on the protection of the groundwater, but also on the protection of the surface environment as well. The rate of percolation to ground- water is higher in the karst regions thus inhibiting the natural mechanical and biological self-purification of the polluted rainwater that passes through the subterranean cavities [22]. Any pollutants on the surface have the potential to percolate into the groundwater as well. The bigger problem is that once the pollution enters the groundwater, it is difficult to trace its source [23] and by the time it is detected, the pollutant is likely to be widespread and the damage is already irreversible [24].

\section{Conclusions and Recommendations}

The community within Panglao Island was not aware of the situation because the negative effect of anthropogenic activities to the environment appears to be virtually absent. These findings clearly suggest the vulnerability of the groundwater resources from human activities because of its hidden location (see also [14]). Repercussions of human activities may not be manifested yet while the disturbance is ongoing, but sooner or later their long term effect will be more apparent.

As in the case of Panglao Island, many areas around the world are unfavorably impacted by tourism and threatened by its associated activities, thus, understanding the physiology of underground ecosystem is critically important so that a proper management plan will be im- 
plemented. Reference [7] recommended that the surface environment should be protected in order to preserve a good groundwater quality. Therefore, revisiting the current local policy with regards to environmental protection is quite appropriate so that necessary measures will be improved and not be overlooked. Higher standard for the coastal development plan, strict environmental monitoring, especially of groundwater, and public awareness on coastal issues will be beneficial to all concerned especially those people relying on coastal resources.

\section{Acknowledgements}

We would like to thank the people of Panglao Island who participated in the survey and the local government staffs and mayors of the municipalities of Panglao and Dauis for permitting and supporting this study as well as for providing some local data. Our sincere gratitude is also expressed to Dr. C.G.B. Banaay whose constructive comments and suggestions helped improve this manuscript. The first author is grateful for the assistance provided by the Yokohama National University during his postdoctoral research fellowship. This work was supported in part by Global COE Program, MEXT, Japan.

\section{REFERENCES}

[1] P. Lamoreaux and J. Newton, "Catastrophic Subsidence: An Environmental Hazard, Shelby County, Alabama," Environmental Geology, Vol. 8, No. 1, 1986, pp. 25-40.

[2] J. De Waele and R. Follesa, "Human Impact on Karst: The Example of Lusaka (Zambia)," International Journal of Speleology, Vol. 32, No. 1-4, 2003, pp. 71-83. http://dx.doi.org/10.5038/1827-806X.32.1.5

[3] J. A. Cuesta and K. Anger, "Larval Morphology and Salinity Tolerance of a Land Crab from West Africa, Cardisoma armatum (Brachyura: Grapsoidea: Gecarcinidae)," Journal of Crustacean Biology, Vol. 25, No. 4, 2009, pp. 640-654. http://dx.doi.org/10.1651/C-2551.1

[4] B. C. Shock, C. M. Foran and T. A. Stueckle, "Effects of Salinity Stress on Survival, Metabolism, Limb Regeneration, and Ecdysis in Uca pugnax," Journal Crustacean Biology, Vol. 29, No. 3, 2009, pp. 293-301. http://dx.doi.org/10.1651/08-2990.1

[5] J. S. Mattice, M. B. Burch, S. C. Tsai and W. K. Roy, "A Toxicity Testing System for Exposing Small Invertebrates and Fish to Short Square Wave Concentrations of Chlorine," Water Research, Vol. 15, No. 7, 1981, pp. 923927. http://dx.doi.org/10.1016/0043-1354(81)90149-4

[6] J. M. Capuzzo, "The Effects of Free Chlorine and Chloramines on Growth and Respiration Rates of Larval Lobster (Homarus americanus)," Water Research, Vol. 11, No. 12, 1977, pp. 1021-1024. http://dx.doi.org/10.1016/0043-1354(77)90001-X

[7] D. E. M. Husana and M. Yamamuro, "Groundwater Quality on Karst Regions in the Philippines," Limnology,
Online First, 6 Feb 2013.

[8] P. Bouchet, P. K. L. Ng, D. Largo and S. H. Tan, "Panglao 2004-Investigations of the Marine Species Richness in the Philippines," The Raffles Bulletin of Zoology, Supplement No. 20, 2009, pp. 1-19.

[9] P. K. L. Ng, D. Guinot and T. M. Iliffe, "Revision of the Anchialine Varunine Crabs of the Genus Orcovita Ng \& Tomascik, 1994 (Crustacea: Decapoda: Brachyura: Grapsidae), with Descriptions of Four New Species," The Raffles Bulletin of Zoology, Vol. 44, No. 1, 1996, pp. 109134.

[10] P. K. L. Ng and D. Guinot, "On the Land Crabs of the Genus Discoplax A. Milne Edwards, 1867 (Crustacea: Decapoda: Brachyura: Gecarcinidae), with Description of a New Cavernicolous Species from the Philippines," The Raffles Bulletin of Zoology, Vol. 49, 2001, pp. 311-338.

[11] P. K. L. Ng, "New Species of Cavernicolous Crabs of the Genus Sesarmoides from the Western Pacific, with a Key to the Genus (Crustacea: Decapoda: Brachyura: Sesarmidae)," The Raffles Bulletin of Zoology, Vol. 50, 2002, pp. 419-435.

[12] Y. Kano and T. Kase, "Genetic Exchange between Anchialine Cave Populations by Means of Larval Dispersal: The Case of a New Gastropod Species Neritilia cavernicola," Zoological Scripta, Vol. 33, No. 5, 2004, pp. 423437. http://dx.doi.org/10.1111/j.0300-3256.2004.00159.x

[13] D. E. M. Husana, T. Naruse and T. Kase, "Two New Cavernicolous Species of the Genus Sundathelphusa from Western Samar, Philippines (Decapoda: Brachyura: Parathelphusidae)," Journal of Crustacean Biology, Vol. 29, No. 3, 2009, pp. 419-427. http://dx.doi.org/10.1651/08-3081.1

[14] D. E. M. Husana, T. Naruse and T. Kase, "A New Species of the Genus Karstarma (Decapoda: Brachyura: Sesarmidae) from Anchialine Caves in the Philippines," The Raffles Bulletin of Zoology, Vol. 58, 2010, pp. 65-69.

[15] D. E. M. Husana, "Cave Ecology in the Philippines, a Conservation Perspective: Linking Surface and Subsurface Ecosystems," PhD Thesis, The University of Tokyo, 2010.

[16] D. E. M. Husana, S. H. Tan and T. Kase, "A New Genus and Species of Anchialine Hymenosomatidae (Crustacea, Decapoda, Brachyura) form Samar, Philippines," Zootaxa, Vol. 3209, 2011, pp. 49-59.

[17] A. Fosshagen and T. M. Iliffe, "Boholina, a New Genus (Copepoda: Calanoida) with Two New Species from an Anchialine Cave in the Philippines," Sarsia, Vol. 74, No. 3, 1989, pp. 201-208.

[18] American Public Health Association, "Standard Methods for the Examination of Water and Wastewater," 21st Edition, American Public Health Association (APHA), Washington DC, 20005.

[19] J. Ward and M. Palmer, "Distribution Patterns of Interstitial Freshwater Meiofauna over a Range of Spatial Scales, with Emphasis on Alluvial River-Aquifer Systems," Hydrobiologia, Vol. 287, No. 1, 1994, pp. 147-156. http://dx.doi.org/10.1007/BF00006903

[20] J. Gibert, J. A. Stanford, M. J. Dole-Olivier and J. V. 
Ward, "Basic Attributes of Groundwater Ecosystems and Prospects for Research," In: J. Gibert, D. L. Danielopol and J. A. Stanford, Eds., Groundwater Ecology, Academic, New York, 1994, pp. 7-40.

[21] C. M. Hall, "Trends in Ocean and Coastal Tourism: The End of the Last Frontier?" Ocean Coastal Management, Vol. 44, No. 9-10, 2001, pp. 601-618. http://dx.doi.org/10.1016/S0964-5691(01)00071-0

[22] F. A. Assaad and H. Jordan, "Karst Terranes and Environmental Aspects," Environmental Geology, Vol. 23, No. 3, 1994, pp. 228-237.
http://dx.doi.org/10.1007/BF00771793

[23] P. J. Wood, J. Gunn and S. D. Rundle, "Response of Benthic Cave Invertebrates to Organic Pollution Events," Aquatic Conservation: Marine Freshwater Ecosystem, Vol. 18, No. 6, 2008, pp. 909-922. http://dx.doi.org/10.1002/aqc.933

[24] P. J. Hancock, A. J. Boulton and W. F. Humphreys, “Aquifers and Hyporheic Zones: Towards an Ecological Understanding of Groundwater," Hydrogeology Journal, Vol. 13, No. 1, 2005, pp. 98-111. http://dx.doi.org/10.1007/s10040-004-0421-6 